\title{
PENINGKATAN KOMPOTENSI GURU AGAMA HINDU MELALUI PEMBINAAN OBSERVASI KELAS DI GUGUS 2 KINTAMANI KABUPATEN BANGLI SEMESTER GANJIL TAHUN PELAJARAN 2018/2019.
}

\author{
Oleh : \\ I Wayan Suardana \\ Pengawas Pendidikan Agama Hindu Tingkat SD Kecamatan Kintamani Kabupaten Bangli \\ paseksarjana@gmail.com
}

Diterima 11 Oktober 2018, direvisi 6 Pebruari 2019, diterbitkan 29 Maret 2019

\begin{abstract}
The aims of this study is to improve the competence of Hinduism teachers at the elementary level in $2^{\text {nd }}$ Group of Kintamani district, and in Bangli Regency. This study is a Regional School Action Research (PTSW) using three cycles design and each cycle consists of four stages, namely: planning, action, observation, and reflection. A measurement technique in the form of test is used to carry out the teaching and learning process. Then, an observation in teaching and learning process are used to collected a quantitative data and it presented in the form of qualitative data. Furthermore, based on the results of this study, it can be found that; first, at the end of the first and second cycles there was an increase in the average results of teacher's potential through training in making lesson plan of 2013 Curriculum from 76.00 to 85.60 after the second and third cycles at the professional level the teacher achieved good grades. Second, it turned out that the increase in teacher's Compensation through classroom observation guidance in the $2^{\text {nd }}$ group in Kintamani and in Bangli regency 2018/2019 showed very significant results from the initial conditions before receiving training. It turns out that teacher training through classroom observation is very useful to increase teacher's potential. However, they can increase their confidence in carrying learning tasks.
\end{abstract}

Keywords: Increased Teacher Compensation Through Fostering Class Observation of $2^{\text {nd }}$ Group in Kintamani.

\section{PENDAHULUAN}

Berdasarkan undang-undang No 20 th 2003 tentang sistem pendidikan Nasional mengamanatkan kepada, semua insan pendidik untuk terus berinovasi, kreatif dan aktif dalam upaya memajukan pendidikan. Kemajuan pendidikan sangat tergantung dari kualitas pendidik.

Untuk meningkatkan kualitas pendidikan nasional semua komponen pendidikan harus ditingkatkan kualitasnya termasuk guru itu tersendiri, karena guru tidak bisa digantikan oleh teknologi canggih apapun dalam proses pembelajaran. Pembaharuan sistem pendidikan nasional telah ditetapkan visi, misi dan strategi pembangunan pendidikan nasional. Visi pendidikan nasional adalah terwujudnya sistem pendidikan sebagai pranata sosial yang kuat dan berwibawa untuk memberdayakan semua warga negara Indonesia berkembang menjadi manusia yang berkualitas sehingga mampu dan proaktif menjawab tantangan zaman yang selalu berubah.

Terkait dengan visi tersebut telah ditetapkan serangkaian prinsip 
penyelenggaraan pendidikan untuk dijadikan landasan dalam pelaksanaan reformasi pendidikan. Salah satu prinsip tersebut adalah pendidikan diselenggarakan sebagai proses pembudayaan dan pemberdayaan peserta didik yang berlangsung sepanjang hayat. Dalam proses tersebut diperlukan guru yang memberikan keteladanan, membangun kemauan, dan mengembangkan potensi dan kreativitas peserta didik. Implikasi dari prinsip ini adalah pergeseran paradigma proses pendidikan, yaitu dari paradigma pengajaran ke paradigma pembelajaran. Pembelajaran adalah proses interaksi peserta didik dengan guru dan sumber belajar pada suatu lingkungan belajar. Proses pembelajaran perlu direncanakan, dilaksanakan, dinilai, dan diawasi agar terlaksana secara efektif dan efisien. Untuk meningkatkan kompetensi guru perlu terus dilaksanakan pembinaan oleh pengawas baik dalam perencanaan pembelajaran maupun proses pembelajaran di kelas.

Dengan diterapkannya Kurikulum 2013 maka banyak perubahan pola mengajar guru sehingga sanagt penting dilakukan pembinaan observasi kelas. Dalam kurikulum 2013, Peranan guru begitu sentral dalam upaya peningkatan mutu pendidikan di Indonesia. Hal ini didasari pemikiran bahwa titik berat pembangunan pendidikan diletakkan pada peningkatan mutu setiap jenjang dan jenis pendidikan juga akan sangat dipengaruhi oleh profesionalisme guru, sehingga kompetensi guru perlu terus ditingkatkan atau dengan kata lain kinerja guru di tuntut harus maksimal. Pembangunan dibidang pendidikan telah diupayakan dengan perbaikan kurikulum, pemenuhan sarana dan prasarana pendidikan, sistem evaluasi, pengembangan bahan ajar, pelatihan guru dan tenaga pendidik, serta kerjasama dengan Komite Sekolah. Peningkatan kompetensi guru dalam pelaksanaan proses belajar mengajar bagian dari usaha peningkatan mutu guru. Guru mempunyai peranan yang sangat penting yaitu sebagai perencana, pelaksana dan dinamisator bahan ajaran yang dilaksanakan sesuai dengan tingkat dan perkembangan peserta didik melalui penguasaan kelas berdasarkan strategi belajar mengajar. Peran atau kemampuan guru dewasa ini masih dinilai jauh dari harapan, sehingga harus ada upaya pembinaan tertentu. Banyak upaya untuk meningkatkan kemampuan profesional guru. Salah satu kegiatan yang dapat dilakukan adalah dengan sistem pembinaan dan pelatihan profesionalisme guru dalam kegiatan Observasi kelas.

Saat pelaksanaan proses pembelajaran guru wajib mempersiapkan Adminitrasi dan prangkat pembelajaran termasuk Rencana Pelaksanaan Pembelajaran ( RPP ). Berdasarkan hasil supervisi dapat disimpulkan bahwa masih banyak guru yang belum mampu mengimplementasikan RPP di kelas. Di Gugus 2 Kintamani sebagai sekolah inti yang sering digunakan untuk pertemuan KKG. Untuk mengetahui tentang kekuatan dan kelemahan Guru dalam Preses Belajar Mengajar sangat efektif dilakukan pengamatan langsung di kelas saat Guru mengajar. Berhasil tidaknya pembinaan yang dilakukan secara rutin kepada guru, akan tercermin dalam Proses Belajar Mengajar di kelas. Pembinaan Observasi kelas merupakan salah satu metode yang dilakukan Pengawas untuk mencari fakta tentang kekuatan dan kelemahan guru. Berdasarkan temuan dari pengamatan langsung maka pengawas dapat mengkaji, menganalisis dan menindaklanjuti kelemahan guru untuk dilakukan pembinaan. Berdasarkan kenyataan itu maka pengawas berinisiatif melakukan pembinaan atas hasil temuan dan tindaklanjut kajian hasil pengawasan dalam bentuk karya tulis Penelitian Tindakan Sekolah. Peningkatan kemampuan guru dalam Proses Belajar Mengajar sangat penting dan mendesak dilaksanakan. Terbatasnya waktu serta biaya maka pelaksanaan Pembinaan Kompotensi Guru Melalui Observasi Kelas Di Gugus 2 Kintamani Kabupaten Bangli Semester Ganjil Tahun Pelajaran 2018/2019 dilaksanakan saat jam mengajar sesuai jadwal Guru agama Hindu. Gugus merupakan tempat paling tepat sebagai bengkel kerjanya 
guru untuk meningkatkan kompetensi guru menghadapi permasalahan tentang penerapan perangkat pembelajaran di kelas.

Beberapa identifikasi permasalahan yang dihadapi guru antara lain:

1. Rendahnya pemahaman guru dalam mengaktifkan siswa di kelas.

2. Rendahnya kemampuan/kompetensi guru mengimplementasikan RPP sesuai standar Proses.

3. RPP yang dipahami sebelumnya belum menunjukan karakteristik sekolah sesuai harapan Kurikulum yang diimplementasikan dalam Pembelajaran.

4. Kurang Aktifnya Gugus Pendidikan Agama Hindu tingkat SD di Kecamatan Kintamani Kabupaten Bangli untuk meningkatkan Kompetensi guru.

Begitu banyaknya permasalahan yang dihadapi guru namun yang paling mendasar menjadi pokok permasalahan untuk diteliti adalah rendahnya kemampuan/kompetensi guru dalam mengimplementasikan RPP Kurikulum dengan mengaktifkan Gugus di Kecamatan Kintamani. Proses pembelajaran akan berjalan efektif dan menyenangkan jika perencanaan dari persiapan mengajar memenuhi standar proses.Tujuan kegiatan ini : (a) Untuk meningkatkan kompetensi Guru Agama Hindu tingkat SD di Gugus 2 Kecamatan Kintamani Kabupaten Bangli dalam Proses Belajar Mengajar. (b). Untuk mengaktifkan Gugus 2 di Kecamatan Kintamani Kabupaten Bangli dalam mengimplementasikan perangkat Pembelajaran pada Proses pembelajaran. Manfaat Penelitian adalah berguna untuk meningkatkan mutu pendidikan agama Hindu di Gugus 2 Kecamatan Kintamani Kabupaten Bangli. Bagi guru untuk meningkatkan profesionalisme dan kompetensi guru dalam Proses Belajar Mengajar. Bagi siswa, mengaktifkan peserta didik untuk memahami materi pembelajaran yang telah disiapkan secara matang oleh guru melalui RPP sesuai kebutuhannya.
Menurut Penelitian Tindakan Sekolah yang dialakuakn oleh Made Nasib Mardika (2013:3) yang menyitir pendapat ahli Pendidikan Sahertian \& Ida Aleida (1992: 42) berpendapat tentang kemampuan guru, bahwa "guru yang tingkat berpikirnya abstrak dan imajinatif yang tinggi, punya kemampuan untuk berdiri di depan kelas dan dengan mudah menghadapi masalah-masalah belajar mengajar seperti manajemen kelas, disiplin, menghadapi sikap acuh tak acuh dari siswa dan mampu menentukan alternatif pemecahan masalah. Ia juga dapat merancang berbagai program belajar dan dapat memimpin siswa dari berpikir nyata ke berpikir konseptual. Seorang guru yang mempunyai kemampuan tinggi akan memiliki kepedulian terhadap tugas, kebutuhan siswa, teman sejawat atau atasan langsung. Ia punya tanggung jawab terhadap tugas yang dibebankannya, termasuk tanggung jawab terhadap bangsa, negara dan sesama manusia.

Berdasarkan pendapat di atas memiliki kesamaan bahwa kemampuan guru dalam melaksanakan tugas pokoknya berupa merencanakan, melaksanakan, mengevaluasi, menganalisis materi pembelajaran dan hasilnya. Jika guru mampu merencanakan Proses Pembelajaran yang dituangkan dalam bentuk RPP dengan baik dan sesuai tuntutan Kurikulum berdasarkan peraturan yang berlaku sesuai perkembangan dunia pendidikan maka guru percaya diri melaksanakan tugasnya sebagai pendidik. Rancangan Pelaksanaan Pembelajaran (RPP) merupakan hal yang mendasar untuk dipersiapkan sebelum guru mengajar karena semua sekenario dan langkah-langkah proses belajar mengajar sudah tertuang dalam RPP. Jika guru dalam membuat RPP senantiasa hanya menjiplak tidak pernah mampu mengembangkan dirinya untuk mandiri tidak mungkin akan mampu memandirikan siswanya. Karena tuntutan keberhasilan dalam pendidikan sesuai pepatah guru patut digugu dan ditiru artinya setiap prilaku guru 
harus mencerminkan prilaku mendidik sehingga guru adalah panutan.

Berdasarkan PTS dari Banmbang Rahono (2003:5) bahwa kemampuan Guru mengajar merupakan kunci keberhasilan. Sekolah yang memiliki guru dengan komitmen tinggi terhadap peningkatan mutu, guru tersebut akan cepat berkembang karena kunci keberhasilan tersebut sangat tergantung kinerja gurunya yang diimplementasikan dalam Proses Belajar mengajar di kelas. Menurut Pidarta (1990) dalam Pelangi (2005:23) guru merupakan kunci kesuksesan sekolah dalam mengadakan perubahan. Kegiatan meningkatkan dan memperbaiki program, perencanaan dan pelaksanaan serta evaluasi dari proses pembelajaran kesuksesanya terletak pada kesungguhan, kreatifitas, inovasi, komitmen, rasa ingin tahu untuk mengembangkan kompetensinya, merupakan cerminan dari karakter diri guru yang ditularkan pada siswanya.

Menurut pendapat tersebut bahwa semua warga sekolah memegang peranan penting untuk mendukung keberhasilan peningkatan mutu pendidikan. Peranan Gugus akan terwujud dalam memecahkan masalah guru, dan berupaya meningkatkan kompetensinya serta tidak terlepas dari dukungan warga sekolah. Maka setiap sekolah memiliki kewajiban untuk memotivasi para guru agar berperan aktif dalam Gugus, KKG dan MGMP. Karena setiap persoalan dan permasalahan akan dapat dipecahkan di Gugus, KKG dan MGMP dengan mengundang para narasumber yang berkompeten dibidangnya masing-masing untuk mensukseskan program pembelajaran yang berkarakter. Bagi guru yang belum paham terhadap pemberlakuan Kurikulum sangat perlu sering dilatih dari pembuatan RPPnya sampai penerapanya dalam kegiatan pembelajaran di kelas. Pembinaan Guru Pendidikan Agama secara nasional dilakukan oleh Direktur Jenderal atau pejabat yang diberi tugas oleh Menteri. Pembinaan Guru Pendidikan Agama tingkat Provinsi dilakukan oleh Kepala Kantor Wilayah Kementerian Agama. Pembinaan Guru Pendidikan Agama tingkat Kabupaten/Kota dilakukan oleh Kepala Kementerian Agama Kabupaten/Kota. Pembinaan sebagaimana dimaksud diarahkan untuk meningkatkan kompetensi dan kualifikasi melalui pendidikan, pelatihan, sertifikasi, pengayaan wawasan dan pengalaman, pemagangan, apresiasi, kompetisi, penugasan, keikutsertaan dalam organisasi profesi pendidik, dan bentuk lainnya. Organisasi profesi pendidik untuk melakukan pembinaan terdiri dari FKG-PA, KKG-PA, MGMP-PA dan organisasi profesi sejenis.

\section{Metodologi Penelitian}

Metode yang dipakai untuk mengumpulkan data penelitian ini adalah wawancara dan observasi. Wawancara adalah untuk memperoleh informasi yang diperlukan untuk melengkapi data dalam penelitian, maka wawancara sangat penting diperlukan untuk kelancaran proses penelitian (Singarimbun, 1995:175). Teknik wawancara/Interview adalah pecakapan langsung antara pewawancara dengan yang diwawamcarai.

Metode wawancara digunakan dalam penelitian untuk tujuan tertentu, agar mendapat keterangan atau pendirian secara lisan dari respondent, dengan bercakap-cakap atau bertatap muka langsung kepada orang yang diwawancarai itu (Koentjakraningrat, 1977:162). Wawancara sebagai metode dipergunakan untuk mendapatkan data-data, keterangan-keterangan, pendirian-pendirian mengenai pokok masalah supaya hasil yang didapatkan mencakup keseluruhan. Mengenai wawancara mendalam dilakukan terhadap informan tertentu, yakni wawancara kepada orang-orang yang dianggap tahu dan menguasai permasalahan yang sedang diteliti. Untuk mengarahkan pembicaraan pada pokok permasalahan dipergunakan pedoman wawancara.

Suatu pedoman wawancara, tentunya harus benar-benar dapat dimengerti oleh pengumpul data, sebab dialah yang akan menanyakan dan menjelaskan pada responden (Fasial, 2001:52). 
Daftar wawancara dibuat berupa pertanyaan-pertanyaan dipegang oleh peneliti dalam bentuk wawancara antara peneliti dengan subjek yang diteliti dan mengisi daftar wawancara pihak peneliti (Sigit, 2001:100). Pedoman wawancara berguna untuk menghindari kehabisan bahan pertayaan. Wawancara akan lancar jika dapat dirumuskan pertanyaan-pertanyaan dengan sempurna, dan hal itu mata tergantung pada sisi pertanyaan. Isi pertanyaan sebagai pedoman wawancara erat hubunganya dengan pengetahuan peneliti tentang isi pokok permasalahan pada pedoman wawancara yang dipergunakan.

Indikator keberhasilan penelitian ini adalah pada siklus I guru-guru dianggap berhasil apabila mencapai peningkatan kemampuan mengajar sesuai instrument yang dipakai mengukur keberhasilan dari sebelumnya. Pada siklus II diharapkan kemampuan guru meningkat pemahamnya terhadap kekurangan yang dialami guru saat mengajar seperti kurang mengoptimalkan media, pengelolaan kelas dan serta mampu meningkatkan nilainya. Pada siklus III para guru diharapkan sudah mampu tampil menyajikan RPP sesuai Kurikulum 2013 untuk diterapkan dalam kelas dan nilainya mengalami peningkatan.

\section{HASIL DAN PEMBAHASAN}

Hasil setiap siklus dalam penelitian ini senantiasa mengalami peningkatan walaupun belum semuanya memenuhi kreteria ketuntasan minimal dengan predikat baik. Baru satu tahapan dilaksanakan pelatihan Proses Belajar Mengajar penerapan Kurikulum 2013 sudah mengalami peningkatan kompetensi guru yang sangat menggembirakan. Semua peserta pelatihan meminta pembinaan dan pelatihan secara swakarsa dan mandiri dalam wadah Gugus ataupun KKG perlu terus dilanjutkan. Bahkan tindaklanjut dari pengawas agar senantiasa dilakukan observasi kelas dan refleksi saat guru mengajar di kelas.
Harapanya agar semua proses dapat dipantau secara nyata tanpa dibuat-buat dan guru lain/teman sejawat dapat menambah wawasan dengan mendapat imbas pengalaman sekolah lain. Kegiatan ini memang sudah dirancang dan dilaksanakan oleh pengawas Pendidikan agama Hindu Kabupaten Bangli mulai tahun 2013 di berbagai tingkatan dengan uji coba sebanyak 14 lokasi. Selanjutnya semua guru yang pernah diobservasi merindukan kembali agar dilanjutkan oleh pengawas melakukan observasi kelas dan reflleksi PBM saat mengajar di kelas.

Pada siklus I dari 10 guru agama Hindu yang dilatih dan dilakukan penilaian ternyata yang mendapat predikat kurang baik sebanyak 5 orang, predikat cukup 3 orang dan predikat baik 2 orang. Kondisi yang dialami oleh guru agama Hindu tingkat SD di Gugus 2 Kintamani pada siklus I dapat dilihat perubahanya. Setelah diberikan pemahaman praktek Proses Belajar Mengajar terjadi peningkatan yang signifikan. Dari awalnya di siklus I ada mendapat predikat kurang baik di siklus II menjadi tidak ada yang kurang baik. Hasil penilaian dari 10 orang guru yang dilatih 5 orang mendapat nilai cukup, 4 orang mendapat predikat baik dan 1 orang mendapat predikat sangat baik.

Pada siklus ketiga juga mengalami penigkatan yang sangat signifikan walaupun belum semuanya memmenuhi ketentuan persyaratan minimal dengan predikat baik. Perkembangan kemampuan guru meningkat tajam, dari 10 guru yang dilatih dan dinilai hasilnya sebagai berikut : 2 orang mendapat predikat cukup, 6 orang mendapat predikat baik dan 2 orang mendapat predikat sangat baik.

\section{KESIMPULAN}

Berdasarkan hasil analisis data pada Bab IV dapat disimpulkan bahwa Bahwa Pembinaan dan Pelatihan di Gugus 2 Kintamani bagi guru agama Hindu merupakan tempat yang paling tepat, efektif 
dan efesien bagi guru untuk meningkatkan kemampuanya dalam PBM Kurikulum 2013.

Bahwa melalui Pembinaan dan Pelatihan di Gugus 2 Kintamani bagi guru agama Hindu dapat meningkatkan kemampuan/kompetensinya dalam PBM Kurikulum 2013 tahun pelajaran 2018/2019 semester Ganjil. Hasil penelitian ini akan diajdikan acuan bagi pengawas untuk mengetahui tingkat kelemahan dan kekuatan guru dalam rangka Proses pembelajaran. Pengembangan profesional guru akan meningkat jika PBMnya baik sesuai langkahlangkah pembelajaran.

\section{SARAN}

1. Berdasarkan simpulan hasil penelitian dan pembahasan tersebut diatas, maka kami sampaikan saran sebagai berikut:

2. Kepada guru Pendidikan Agama Hindu agar senantiasa mengikuti KKG/MGMP serta pembinaan dan Pelatihan baik di Gugus di Kecamatan maupun di Kabupaten untuk memperluas dan memperdalam pengetahuan dibidang keguruan untuk senjata mengajar agar guru selalu merasa percaya diri tampil di depan kelas.

3. Kepada para pengawas untuk senantiasa melakukan Inovasi teknologi pembelajaran, khususnya yang berhubungan dengan metode peningkatan kualitas guru dengan senantiasa melakukan pelatihan PBM di Gugus melalui KKG/MGMP. Hal ini sesuai dengan hasil penelitian ini yang menunjukan bahwa kegiatan pembinaan dan pelatihan guru dalam PBM Kurikulum 2013 menunjukan hasil yang sangat signifikan.

\section{DAFTAR PUSTAKA}

Badan Standar Nasional Pendidikan. 2007. Peraturan Menteri Pendidikan Nasional Republik Indonesia Nomor 41 Tahun 2007. Jakarta: BSNP.

Dahar, Ratna Wilis. 1989. Teori-Teori Belajar. Jakarta: Penerbit Erlangga.
Depdikbud. 1994. Petunjuk Pelaksanaan Proses Belajar-Mengajar. Jakarta: Direktorat Pendidikan Menengah Umum.

Depdiknas. 1999. Pengelolaan Pengujian Bagi Guru Mata Pelajaran. Jakarta: Direktorat Pendidikan Menengah Umum, Direktorat Jenderal Pendidikan Dasar dan Menengah

Depdiknas. 2002. Contextual Teaching And Learning. Jakarta: Dirjen Pendidikan Dasar dan Menengah.

Degeng I Nyoman S, 2006. Teori dan Konsep Belajar, Surabaya: Program Pascasarjana Universitas PGRI Adibuana.

Depdiknas, 2003. Undang-Undang Republik Indonesia Nomor 20 Tahun 2003 tentang Sistim Pendidikan Nasional, Jakarta: Depdiknas.

Depdiknas, 2005. Peraturan Pemerintah Republik Indonesia Nomor 19 Tahun 2005 tentang Standar Nasional Pendidikan, Jakarta: Mendiknas.

Depdiknas, 2006. Pedoman Pelaksanaan Penelitian Tindakan Kelas, Jakarta: Dit Prodik Dirjen PMPTK.

Departemen Agama RI, 2007. Peraturan Pemerintah Nomor 55 Tahun 2007 tentang Pendidikan agama dan Keagamaan, Jakarta

Depdiknas, 2008. Peraturan Pemerintah nomor 74 tentang Guru, Jakarta.

Dwi Agus Sudjimat, 2004. Metodelogi Penelitian, Surabaya: Program Pascasarjana Universitas PGRI Adibuana. 